\section{Saksan muotoiluhistoriayhdistyksen Designkritik-konferenssi HfG Offenbachissa 19.-20.5.2017}

Satu Kähkönen

Saksan muotoiluhistoriayhdistys (Gesellschaft für Designgeschicte, GfDg) järjesti toukokuussa muotoilujournalismia ja -kritiikkiä käsittelevän konferenssin yhteistyössä Offenbachin muotoilukorkeakoulun (Hochschule für Gestaltung Offenbach am Main, HfG) kanssa. Vuonna 2008 Weimarissa perustetun muotoiluhistoriayhdistyksen tavoitteena on vahvistaa muotoiluhistorian tutkimuksen asemaa, tuoda muotoilualan tutkimusta ja käytäntöjä yhteen ja edistää julkista keskustelua muotoilusta. Yhdistys tekee yhteistyötä alan oppilaitosten ja museoiden kanssa. Yhdistyksen vuosittain järjestämissä konferensseissa teemoina ovat olleet esimerkiksi muotoiluhistorian rooli alan käytännöissä sekä muotoilukeräily ja -kokoelmat.

Tämän vuoden konferenssin pitopaikkana oli Main-joen rannalla, alle kymmenen kilometrin päässä Frankfurtista, sijaitseva HfG Offenbach. Oppilaitoksen juuret ovat vuonna 1832 perustetussa käsityökoulussa, joka muutettiin myöhemmin taide- ja käsityökouluksi. Oppilaitos sai korkeakoulustatuksen 1970-luvulla. Opetukseen ovat vahvasti vaikuttaneet sekä Bauhausin että Ulmin muotoilukoulujen esikuvat. Nykyään oppilaitoksessa voi opiskella muotoilua, taidetta ja mediaa. Vuodesta 2010 alkaen oppilaitoksessa on voinut suorittaa tohtorin tutkinnon. Hessenin osavaltio on tehnyt päätöksen panostaa taidekoulutukseen lähivuosina: HfG Offenbach on saamassa uudet tilat, joiden rakentaminen on tarkoitus alkaa vuonna 2020.

Konferenssin lähtökohtana oli toisaalta journalismin murroksen ja toisaalta muotoilun käsitteen laajentumisen vaikutukset muotoilusta kirjoittamiseen. Kaksipäiväisen konferenssin esitelmissä kysyttiin mm. onko kriittiselle muotoilujournalismille enää sijaa talouden ohjaamien intressien ja mediamaailman muutosten keskellä ja millaiselle muotoilukritiikille olisi tarvetta? Eri taidealojen kriitikot ovat olleet huolissaan kritiikin vähenemisestä perinteisissä medioissa jo pitkään. Sanomalehtien kulttuuriosastoja on supistettu, kritiikkejä julkaistaan aiempaa vähemmän ja paneutuvalle kulttuurijournalismille on yhä vähemmän tilaa. Muotoilukritiikki on ylipäätään sijoittunut marginaaliin: vain harvoissa tapauksissa muotoilusta on kirjoitettu sanomalehdissä yhtä säännöllisesti kuin vaikkapa kuva- 
taiteesta, kirjallisuudesta tai teatterista. Muotoilusta kirjoittaminen on keskittynyt enemmän harvoihin alan ammattilaisille suunnattuihin erikoislehtiin ja sisustuslehtiin. Esitelmissä joissa käsiteltiin muotoilujournalismin nykytilannetta, lähtökohtana oli yleisemminkin nykyjournalismin ongelmaksi koettu pinnallistuminen: kokemus siitä, että muotoilua esitellään pääasiassa vain viihteellisissä tai kaupallisissa yhteyksissä, muotoilusta kirjoitetaan vain ylistäviä arvioita tai kriittiset huomiot leikataan arvioista pois ja muotoilujournalismin tehtäväksi jää vain esineiden nostaminen muotoilun kaanoniin.

Nykytilanteen pohdinnan lisäksi konferenssiesitelmät tarjosivat katsauksia muotoilujournalismin ja -kritiikin historiaan ja samalla saksankielisten maiden muotoiluhistorian keskeisiin aiheisiin. Esitelmissä käsiteltiin myös muotoilukritiikin ja kirjoittamisen roolia nykyisessä muotoilukoulutuksessa. Konferenssi liittyi HfG Offenbachin suunnitelmiin perustaa muotoilukuratointiin ja -kritiikkiin keskittyvä maisteriohjelma. Vastaavia ohjelmia on esimerkiksi Eindhovenin muotoiluakatemiassa ja Kingston yliopistossa Lontoossa.

\section{Mitä muotoilukritiikki on tai mitä sen pitäisi olla?}

Vaikka konferenssin lähtökohdiksi oli kirjattu sosiaalisen median vaikutus muotoilujournalismiin sekä muotoilukäsitteen laajentuminen perinteisestä tuotesuunnittelusta erilaisten prosessien ja järjestelmien suunnitteluun, puheenvuoroissa keskityttiin kuitenkin pääasiassa melko perinteisiin muotoilun ja journalismin muotoihin.

Muotoilukritiikki ymmärrettiin puheenvuoroissa sekä tuotteiden estetiikan ja käytettävyyden arvioinniksi, että tuotteiden roolia yhteiskunnassa tai sosiaalisessa vuorovaikutuksessa laajemmin arvioivaksi kulttuurikriittiseksi pohdinnaksi. Muotoilukritiikkiä käsiteltiin toisaalta journalistisena käytäntönä, mutta toisaalta se ymmärrettiin myös analyysikäytännöksi muotoiluprosessissa tai kriittisen ajattelun välineeksi muotoilijakoulutuksessa.

Vuonna 2014 Essenin taideyliopistosta väitellyt ja HfG Offenbachissa muotoiluteoriaa opettava teollinen muotoilija Thilo Schwer ja Berliinin ammattikorkeakoulussa (HTW Berlin) opettava Birgit Bauer yhdistivät muotoilukritiikin ensisijaisesti muotoilijan ammattitaitoon pohtia suunnitteluun liittyviä
Kuva 1. Muotoiluteoriaa HfG Offenbachissa opettava Thilo Schwer vastasi konferenssin paikallisista järjestelyistä. Kuva: Wolfgang Seibt (Hessinin taide- ja muotoilu-yliopisto).

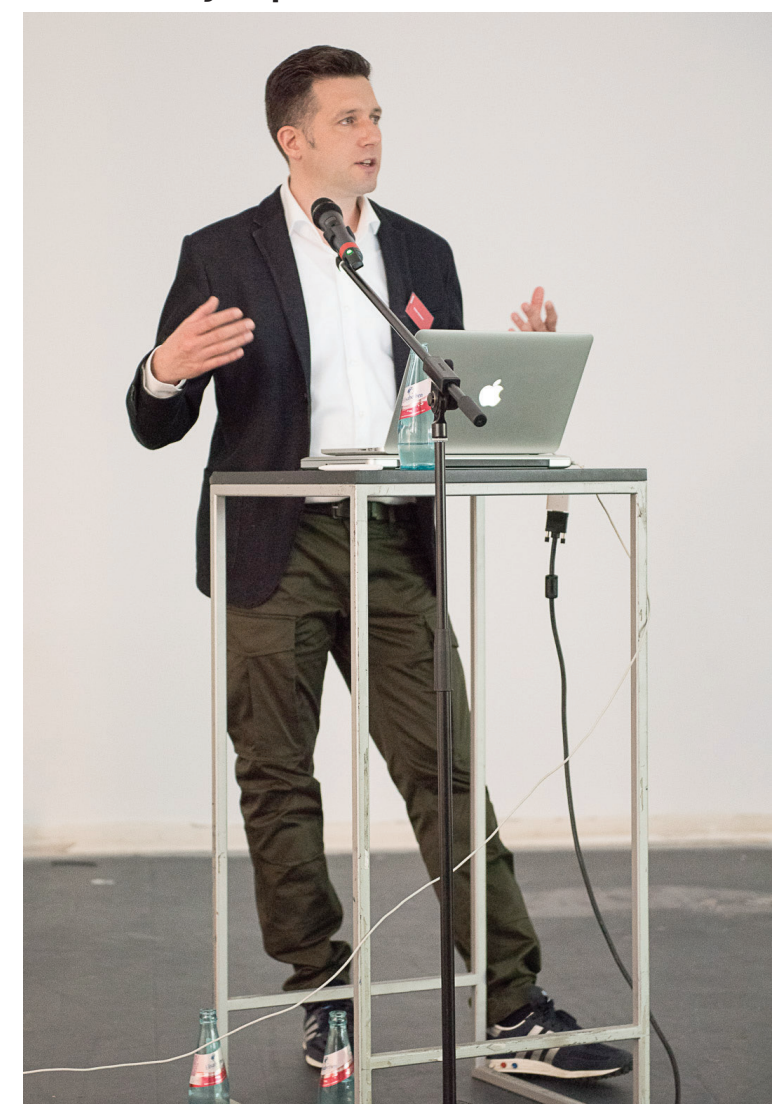

arvoja ja ratkaisuja. Schwer nosti esitelmässään esiin tapoja, joilla muotoilija voi osallistua muotoilukriittiseen keskusteluun. 
Muotoilijat voivat oman ammattitaitonsa pohjalta arvioida ja verrata markkinoilla olevia tuotteita ja kirjoittaa niistä tai he voivat myös suunnitella keskustelua herättäviä tai kantaaottavia tuotteita. Schwerin mukaan muotoilukritiikki voi siis olla sanallista tai visuaalista, uusiin ratkaisuihin tai parannuksiin pyrkivää tai kysymyksiä herättävää. Olennaisempana hän kuitenkin piti kriittisen ajattelun merkitystä itse muotoiluprosessissa, ja sitä että muotoiluopinnot antaisivat valmiuksia analysoida tuotteita eri näkökulmista muotoiluprosessin aikana. Bauer puolestaan kertoi esimerkkejä siitä, miten hän omassa opetuksessaan Berliinin ammattikorkeakoulussa on sisällyttänyt kirjoittamisen ja kritiikin opintoja muotoiluopintoihin. Bauerille kirjoittaminen toimii opetuksessa ensisijaisesti kriittiseen ajatteluun ohjaamisen välineenä. Bauerin kursseilla opiskelijat ovat esimerkiksi perehtyneet muotoiluhistoriasta tunnettuihin manifesteihin ja muotoilufilosofioihin ja pohtineet omaa suunnittelua ohjaavia arvoja tai tavoitteita kirjallisissa töissä.

DDR:n muotoiluhistoriaan erikoistunut toimittaja ja kriitikko Günter Höhne ja muotoilukriitikko ja -konsultti Markus Frenzlin puolestaan keskittyivät puheenvuoroissaan siihen, miten muotoilu näkyy nykymediassa ja miten näkyvyyttä tulisi parantaa. Höhnen mukaan jokapäiväiseen elämään liittyvä muotoilu ei ole saanut saksalaisessa mediassa palstatilaa. Yhteisömuotoilun tai esteettömyyden kaltaisista teemoista ei juuri kirjoiteta. Markus Frenzl puolestaan korosti, että kritiikitön ja "euforistinen" tapa kirjoittaa muotoilusta on lisääntynyt. Berliinissä ja Potsdamissa kirjoittamista opettanut Höhne painotti, että muotoilukriitikoilla tulisi olla muotoiluteorioiden ja -käytäntöjen lisäksi enemmän tietoa erilaisista journalistisista käytännöistä, jotta tärkeitä teemoja saataisiin enemmän esiin. Muotoilu- ja mediateoriaa Münchenissä opettava Frenzl kertoi vuonna 2012 Münchenin ammattikorkeakoulussa aloitetusta opetusohjelmasta, jossa on voinut suuntautua muotoilujournalismiin ja -kritiikkiin. Frenzlin mukaan opetuksen tavoitteena on kokeilla uusia journalistisia tapoja, mutta opintojen puitteissa on julkaistu myös perinteistä painettua DING -lehteä yhteistyössä form-muotoilulehden, Ingolstadtin konkreettisen taiteen museon ja Hansgrohe-yrityksen kanssa.

Mara Recklies, joka valmistelee muotoilukritiikin historiaan ja muutoksiin keskittyvää väitöskirjaansa Christian-Albrechts yliopistossa Kielissä puolestaan vaati muotoilukritiikiltä enemmän kantaaottavuutta. Hän kiinnitti puheenvuorossaan huomiota siihen, että vaikka muotoilun sosiaalisesta vastuusta keskustellaan kansainvälisesti aikaisempaa enemmän, on aiheen tärkeyden huomioon ottaen tietoisesti poliittista muotoilukritiikkiä huomattavan vähän. Muotoilusta kirjoittamisen yhteydessä valmistusmateriaalien ja -menetelmien ekologisuus tai eettisyys tai se mitä tuotteille tapahtuu kun ne poistuvat käytöstä saavat edelleen liian vähän huomiota. Recklies lainasi filosofi Michael Grossmannia, jonka mukaan kriitikon tehtävä on näyttää seuraukset, arvioida niitä ja esittää kysymys, haluammeko todetta tätä? Reckliesin mukaan muotoilukritiikin nostaminen korkeakulttuuriksi sanomalehtien kulttuuripalstoilla hälventää muotoilun poliittisia merkityksiä ja muotoiluun liittyvää vastuuta.

Sveitsiläisessä Hochparterre-lehdessä kulttuuri- ja muotoilutoimittajana toimiva taidehistorioitsija Meret Ernst keskittyi puheenvuorossaan kuvien rooliin muotoilujournalismissa ja -kritiikissä. Esitelmänsä aluksi Ernst kertoi muutaman sanan Hochparterre-lehdestä. Vuonna 1988 pe- 
rustettu lehti käsittelee laajasti arkkitehtuuria ja muotoilua kriittisellä otteella. Hochparterre on työntekijöidensä omistama yritys, joten toimittajat vastaavat itse lehden sisällöstä ja journalistisista valinnoista. Lehdessä artikkelien kuvitusta ei ole delegoitu erillisille kuvatoimittajille vaan kirjoittajat vastaavat myös artikkeliensa kuvista. Esitelmässään Ernst korosti, että kuvilla on ollut keskeinen rooli kuluttajien makukasvatuksessa ja muotoilijan ammattikuvan rakentamisessa. Kuvien avulla on luotu merkityksiä, mutta merkityksiä voidaan myös muuttaa ja rakentaa uudelleen. Ernstin mukaan raja mainostamisen ja toimituksellisen sisällön välillä on vaarassa hämärtyä, jos toimittajat tyytyvät käyttämään tuottajien tarjoamia tuotekuvia kritiikeissään, sen sijaan että tekstiä tukevat kuvat tilattaisiin itsenäiseltä valokuvaajalta. Kun tyydytään tuotekuviin, menetetään mahdollisuus argumentoida yhtä kriittisesti kuvien kuin tekstin välityksellä. Ernstin mukaan kuvien kriittistä potentiaalia ei muotoilukritiikissä hyödynnetä riittävästi.

Muotoilukritiikin ja muotoilujournalismin historiaa

Konferenssissa ei käsitelty vain muotoilukritiikin nykytilaa ja kirjoittamisen roolia muotoilukoulutuksessa. Nykytilanteen pohdintaan toivat perspektiiviä muotoilujournalismin ja -kritiikin historiaa tarkastelevat esitelmät. Samalla ne tarjoisivat kurkistuksen saksalaiseen ja sveitsiläiseen muotoiluhistoriaan ja ajankohtaisiin tutkimusteemoihin. Vaikka Ernstin ja Schwerin esitelmien fokuksessa olivat nykykäytännöt, molemmat taustoittivat nykykäytäntöjä historiasta poimituin esimerkein. Ernst kävi esitelmässään läpi, miten eri tavoin kuvia on käytetty muotoilusta kirjoittamisen yhteydessä 1800-luvun puolelta aina tämän päivän muotoilujournalismiin. Schwer puolestaan havainnollisti, miten muotoilun analyysimenetelmiä on kehitetty Ulmin muotoilukoulun alkuaikojen luonnontieteisiin nojaavista menetelmistä kohti inmiskeskeistä suunnittelua, jossa korostuu esineiden rooli sosiaalisessa vuorovaikutuksessa.

Sonja Sikoran ja René Spitzin esitelmissä keskityttiin muutamiin alan tunnettuihin saksalaisiin lehtiin ja niiden journalistisiin tai muotoilukriittisiin lähestymistapoihin. Sikora aiheena oli 1800-luvun lopussa perustetut taidekäsityö- ja sisustuslehdet kuten Deutsche Kunst und Dekoration (1898-1932) ja Dekorative Kunst (1897-1929) ja niiden ta- vat kirjoittaa sisustuksesta ja taidekäsityöstä. Lehden kuuluvat siihen pitkälti englantilaisten esikuvien pohjalta perustettujen lehtien joukkoon, joilla oli valistustehtävä jonka tavoitteena oli lisätä lukijoiden ymmärrystä taiteesta ja valistaa hyvän maun mukaiseen kodinsisustukseen ja kodinesineiden valintaan. Sikoran mukaan lehtien kirjoitustyyli oli korostetun subjektiivinen. Lehtien kohdeyleisöä olivat sekä alan ammattilaiset että potentiaaliset ostajat. Vuonna 1893 perustetun englantilaisen The Studio-lehden tapaan lehdissä julkaistuilla kuvilla oli keskeinen rooli uusien ideoiden leviämisessä ammattilaisten keskuudessa. Spitz puolestaan tarkasteli form-lehteä, joka perustettiin vuonna 1957 modernia muotoilua, arkkitehtuuria, taiteita, teatteria, elokuvaa ja tanssia käsitteleväksi kulttuurilehdeksi. Vuonna 1966 lehti profiloitui muotoilualan ammattilehdeksi. Spitz havainnollisti, miten muotoilualan ammatillistuminen ja erikoistuminen näkyy lehden sisällössä, tarkastelutavoissa, kielessä ja visuaalisessa ilmeessä. Alkuvaiheessa lehdessä esiteltiin esimerkiksi eri maiden modernia muotoilua ja pyrittiin perustelemaan modernin muotoilun merkitystä ennen toista maailmansotaa ilmestyneiden lehtien tapaan. 1960-luvun 
alussa tarkastelutapa muuttui analyyttisemmäksi ja kriittisemmäksi ja keskeisiksi aiheiksi tulivat esimerkiksi tuotekehitys ja olemassa olevien tuotteiden analysointi. Spitz pitää lehden aikaisempaa kriittisempää otetta osoituksena muotoilualan ammatillistumisesta ja merkkinä siitä, että alalla alkoi olla

tarpeeksi toimijoita kriittisen keskustelun aikaansaamiseksi. Toisena ammatillistumisen merkkinä hän pitää muotoilukritiikin muotojen monimuotoistumista. Tuotekehitystä käsittelevien kirjoitusten ja muotoiluanalyysien lisäksi lehdessä julkaistiin haastatteluja, kommentaareja ja polemiikkeja ajankohtai-

Kuva 2. Kaksipäiväinen konferenssi kokosi Offenbachiin yli 70 kuulijaa ja aiheesta käytiin välillä kiihkeääkin keskustelua. Kuva: Wolfgang Seibt (Hessinin taide- ja muotoilu-yliopisto).

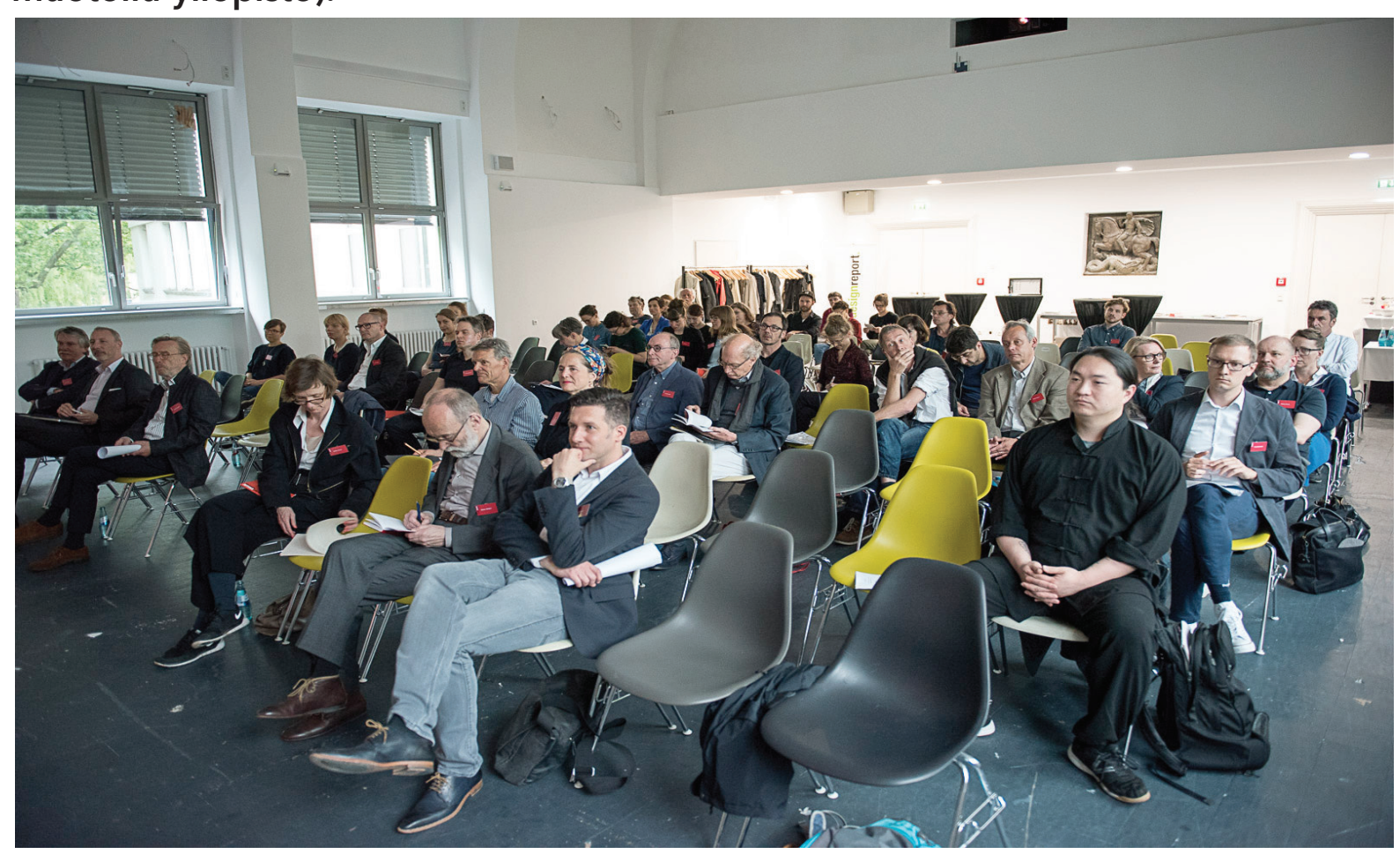

sista aiheista sekä arvioita alan näyttelyistä, kirjallisuudesta ja seminaareista. Lehden kolumneissa muotoilukysymyksiä käsiteltiin myös satiirin keinoin. Kriittinen ote näkyi lehdessä sekä aiheiden valinnassa että käsittelytavassa kuten otsikoinnissa, retoriikassa ja visuaalisessa esittämisessä.

Yves Vincent Grossmannin puheenvuoro liittyi hänen tuoreeseen väitöskirjansa, jossa hän on tarkastellut teollisten muotoilijoiden ammatillistumisen strategioita Länsi-Saksassa ja teollisten muotoilijoiden roolia yrityksissä - mm. BASF, MAN, Siemens ja Rosenthal vuosina 1959-1990. Grossmann keskittyi kriisivuosikymmeneksi usein nimettyyn 1970-lukuun ja vuosikymmenen ajankohtaisin muotoilukeskusteluihin Länsi-Saksassa. Yksi keskeisimmistä keskustelun aiheista 1960-70 -lukujen vaihteessa oli muotoilukoulutus, jonka koettiin olevan kriisissä. Grossmannin mukaan muotoilukoulutusta koskevassa "kriisikeskustelussa" keskeisessä roolissa olivat muotoiluoppilaitosten opettajat. Keskusteluun osallistui toimijoita myös teollisuuden ja politiikan piireistä. Grossmann kuvasi 1970-lukua murroskaudeksi Ulmin muotoiluoppilaitoksen piirissä luotujen ideaali- 
en ja 1980-luvun postmodernien debattien välillä. 1970-luvulla suunnittelijoille avautui uusia mahdollisuuksia mutta vuosikymmen toi mukanaan myös uudenlaisia uhkakuvia ja haasteita. Aktiivista muotoilukriittistä keskustelua käytiin Grossmannin mukaan esimerkiksi Süddeutsche Zeitung, Handelsblatt ja Frankfurter Zeitung -lehtien palstoilla. Grossmann kuvasi, miten kriitikot tasapainottelivat kirjoituksissaan öljykriisien ja talouden taantuman seurauksena vallinneen yhteiskunnallisen kriisitietoisuuden ja alan sisäisten kriisikokemusten, joista keskeisin oli koulutuksen alennustilaa koskeva keskustelu, kaltaisten teemojen välillä. Grossmannin mukaan on yllättävää, että öljykriisiin viitattiin keskustelussa vain harvoin, vaikka se on usein jälkikäteen nostettu keskeiseksi vaikuttimeksi 1970-luvun kriisi-ilmapiirille.

\section{Konferenssin antia}

Vaikka konferenssin puheenvuoroissa valiteltiin muotoilujournalismin pinnallistumista ja muotoilukritiikin saamaa vähäistä palstatilaa, suomalaisesta näkökulmasta saksankielisellä alueella on paljon aktiivisia toimijoita ja mielenkiintoista tarjottavaa muotoilukritiikin ja -journalismin alueella. Monet konferens- sin puhujista ja osallistujista kirjoittavat ja keskustelevat aktiivisesti muotoilusta eri näkökulmista ja eri medioissa: Réne Spitz on arvioinut muotoilunäyttelyitä WDR3 radiokanavalla jo vuodesta 1997 alkaen. Birgit Bauer on puolestaan yksi designkritik.dk-sivuston perustajajäsenistä. Konferenssissa esiteltiin myös muotoilualan opiskelijoille suunnattu Wilhelm Braun-Feldweg kirjoituskilpailu. Kirjoituskilpailusta olivat konferenssissa kertomassa palkinnon jakamisesta vastaava Benita Braun-Feldweg ja palkintolautakunnan puheenjohtaja Egon Chemaitis. Wilhelm Braun-Feldweg (1908-1998) oli teollinen muotoilija ja taidehistorioitsija, joka kirjoitti useita alan oppikirjoja, opetti teollista muotoilua Berliinin taideyliopistossa vuosina 1958-1973 ja oli omalta osaltaan vaikuttamassa muotoilun ammatillistumiseen Saksassa. Hänen nimeään kantava kirjoituskilpailun tavoitteena on nostaa esiin rohkeita ja itsenäisiä muotoilualaa käsitteleviä tekstejä, joissa tartutaan alan ajankohtaisiin kysymyksiin tai haasteisiin syvällisellä otteella. Palkinto on jaettu kuusi kertaa. Ensimmäisinä vuosina palkinto jaettiin joka vuosi, vuodesta 2007 alkaen se on jaettu muutaman vuoden välein. Myös perinteiset muotoilulehdet ovat saaneet jatkaa toimintaansa saksankielisellä alueella kustannusalankriisistä huolimatta. Kriisillä on toki ollut vaikutuksensa: form-lehteä vuodesta 2002 alkaen julkaissut Birkhäuser-kustantamo ajautui konkurssiin vuonna 2012. Lehden toiminta saatiin kuitenkin jatkumaan ja tänä vuonna lehti juhlii kuusikymmenvuotista taivaltaan. Myös vuodesta 1988 julkaistu Hochparterre-lehti on edelleen voimissaan.

Konferenssi tarjosi tilaisuuden tutustua muotoiluhistoria yhdistyksen toimintaan, saksankielisten maiden muotoiluhistorian aktiivisiin toimijoihin ja ajankohtaisiin tutkimusaiheisiin. Konferenssin loppupuolella Sarah Klein ja Sandra Bischler Baselin muotoilu- ja taidekorkeakoulusta (FHNW HGK Basel) kertoivat vuonna 2016 käynnistyneestä sveitsiläisen graafisen suunnittelun ja typografian historiaan keskittyvästä tutkimusprojektista. Sveitsiläisestä graafisesta suunnittelusta tuli kansainvälisesti tunnettua 1950-60-luvuilla. Tähän vaikuttivat lähinnä Zürichissä ja Baselissa vaikuttaneet opettajapersoonat, institutionaaliset raamit ja ammatilliset verkostot. Tutkimusprojektissa näkökulmaa pyritään laajentamaan vähemmän tunnettuihin henkilöihin ja arkistomateriaaliin. 
Muotoiluhistorian tutkijoille Saksa tarjoaa monia mielenkiintoisia mahdollisuuksia. Vanhemman muotoiluhistorian tutkijoille Berliinin Kunstbibliotek on perinteisesti ollut aarreaitta, jossa saksankielisten maiden muotoilu- ja sisustuslehtien ja alan kirjallisuuden lisäksi myös esimerkiksi ruotsalaisiin ja englantilaisiin aikalaisjulkaisuihin on voinut tutustua yhdessä paikassa. Uudemmasta muotoilusta kiinnostuneille Saksan muotoiluyhdistyksen kirjasto Frankfurtissa on tutustumisen arvoinen paikka. Nykyään monia aineistoja on saatavilla myös verkossa. Sonja Sikoran esitelmässä tarkastelemia lehtiä voi lukea esimerkiksi Heidelbergin yliopiston kirjaston verkkosivuilla. Form-lehden näköisversiot vuodesta 1953 vuoteen 2011 on luettavissa lehden verkkosivulta löytyvästä arkistosta. Günter Höhe puolestaan on koonnut mielenkiintoisen sivuston DDR:n muotoilusta kiinnostuneille.

Konferenssissa kuultiin 16 esitelmää ja se kokosi Offenbachiin yli 70 kuulijaa. Esitelmien pohjalta on suunnitteilla artikkelikokoelma, joka on tarkoitus julkaista muotoiluhistoriayhdistyksen vuonna 2018 järjestettävän konferenssin yhteydessä..

\section{Linkkejä}

Gesellschaft für Designgeschichte / www.gfdg.org Hgf Offenbach / www.hfg-offenbach.de

form-lehden arkisto / www.form.de

Hochparterre-lehti / wwww.hochparterre.ch

René Spitz / renespitz.de

Yves Vincent Grossmann / yvesvincentgrossmmann. info

Günter Höhne / www.industrieform-ddr.de/

\section{wordpress/}

Thilo Schwer / thilo-schwer.de

Dessignkritik / www.dessignkritik.dk

Swiss Graphic Design and Typography Revisited -tutkimusprojekti / www. 4 gzl. de

Wilhelm Braun-Feldweg preis / www.bf-preis.de

Saksan muotoiluyhdistyksen kirjasto / https://www. german-design-council de/en/about/library/

\section{FT Satu Kähkönen on erikoistunut} 1800-1900-lukujen arkkitehtuurin ja muotoilun historian tutkimukseen. 